\title{
Research on the Human Resource Management in Small and Medium Enterprises
}

\author{
Xin Yan \\ Fuzhou University of International Studies and Trade \\ Fuzhou, China
}

\begin{abstract}
The human resources management system is not perfect in today's SMEs due to relatively backward management mode, insufficient recruitment work, lack of effective employee incentive mechanism, lack of scientific compensation system, insufficient staff training and neglect of corporate culture construction. This paper analyzes the reasons of the above problems and proposes a series of solutions.
\end{abstract}

Keywords-SMEs; human resource management; compensation

\section{INTRODUCTION}

The large number of small and medium-sized enterprises play an irreplaceable role in China's national economy. They promote the rapid development of the economy, promote social harmony and stability, and play a positive role in ensuring the stable and moderate growth of the national economy, alleviating social employment pressure and optimizing and improving economic results. Although small and medium-sized enterprises are growing, their overall level of development is low, and there are many problems in the actual management. Therefore, small and medium-sized enterprises must strengthen the management of human resources in order to rise suddenly in the whole industry.

\section{CURRENT Status OF HuMAN RESOURCES}

\section{MANAGEMENT SySTEM IN SMES IN FUJIAN PROVINCE}

\section{A. The System of Human Resources Management Is Not Sound}

SMEs are limited by their size, in their initial stage, few SMEs will hire full-time human resources management personnel. In order to save costs, many human resources affairs are even completed by the boss himself. SMEs are short of time, capital and professional knowledge in the initial stage. Its human resource management model is relatively backward due to lack of attention to human resources management and scientific human resource management system. In many family businesses, the management methods are more casual and rude, employees are very dissatisfied. There are some problems in the human resource management system of small and medium-sized enterprises in China with the change of external competitive environment [1]. The practice has shown that fast-growing SMEs pay more attention to establishing a complete human resources system, such as how to train employees, establish a standardized compensation and welfare system and make reasonable career planning for employees and so on, which have had a positive impact in the company's overall operations.

\section{B. Staff Recruitment Management Is Not Well Done}

With the development of education in China, the number of university graduates has increased from 1.14 million in 2001 to 8 million in 2017. However, most of China's enterprises and university graduates face a dilemma at the same time: insufficient workers for companies and insufficient work chances for college graduates. There are multiple reasons for this dilemma such as lack of mediumand long-term human resources plans, lack of recruitment plans, lack of a solid foundation for recruitment, incomplete process of recruitment management, ineffectively and formalistic recruitment work. In addition, SMEs are short of proper positioning for recruiting talents, a clear development strategy and mentality of actively recruiting talents. In many SMEs, the selection of recruitment strategy and channel is inappropriate and too simple, the interview arrangement is unreasonable, the scientific quality evaluation system is missing, the talent information reserve is lacking and the professional level is generally low.

\section{Lack of Effective Employee Incentive Mechanism}

China's small and medium-sized enterprises are mostly family-owned enterprises. Many business owners are personally engaged, the power is concentrated, the internal organizational structure is simplified, and the management power is unified in the hands of the owners. Many employees are relatives of managers, so although it is convenient to organize, it is very easy to dampen the enthusiasm of some non-family employees. Compared with large enterprises, SMEs have a backward management mode and lack of incentive mechanism. Even if there are incentives, most of them are short-term incentives, such as bonuses and prizes. It is difficult to use long-term incentive schemes, such as stock options, employee stock ownership, seniority wages and etc. The long-term incentive mechanism is rarely used in SMEs, which dampens the enthusiasm, initiative and creativity of senior executives and is not conducive to employees' potential in the enterprise. 


\section{Lack of Scientific Compensation System}

So far many SMEs do not have a scientific compensation management system. The wage standards of employees are even determined by the leaders of the company. The employees cannot calculate their income through the compensation system and often feel unfair, which will lead to the loss of employees [2]. In fact, the compensation system has a great influence on employee satisfaction and a reasonable compensation system can be used to motivate employees and stabilize the workforce. If the employee's compensation is lower than other companies, employees will resign and make company unstable.

\section{E. Insufficient Staff Training}

Due to the limitations of their own conditions, SMEs have been exhausted in production management, product development and technological development, so it is difficult to invest more funds in staff training. Therefore, many small and medium enterprises invest little in staff training It was found that the staff training in many SMEs was only formalistic, which led to employees being less willing to participate and poor training effect by investigation and study. Many companies have not conducted in-depth analysis of the current training needs and reasons. For example, in the on-the-job training of employees, they did not analyze in depth the problems that arise in the current work and what form of training should be taken to address these issues. Many companies neglect the training of senior personnel. They think that only the junior managers and common staffs need to be trained and the middle and senior management personnel do not need training because they are competent talents. But in fact, the training of senior staff is also very important, most of the bosses and managers of private enterprises are not highly educated in particular. Senior managers do not know anything about modern tools such as foreign languages and computer software. The restrictions on the management level of SME managers will inevitably affect the effectiveness of employee training.

\section{F. Neglect of Corporate Culture Construction}

In China, most SMEs have little awareness of cultural construction. Even if some enterprises have done some corporate culture construction, they are also formalistic, such as singing, dancing and holding competitions, which have no practical effects. In addition, small and medium-sized enterprises are mostly family-run, which makes employees lack the sense of responsibility and belonging. They have not yet incorporated corporate culture into the scope of human resources management and paid full attention to them. Therefore, if the management is improper, enterprise employees will lack of cohesion.

\section{THE ANALYSIS OF THE REASONS THAT AFFECT THE MANAGEMENT OF HUMAN RESOURCES IN SMES}

These problems are caused by many reasons. Only when a company achieves a win-win situation for both enterprises and employees can it develop steadily. If employees feel that the company cannot provide them a platform for career exploration, career establishment and professional satisfaction, they may change jobs to seek career advancement and realize self-worth. The reason is as follows:

\section{A. Lack of Human Resources Staff}

20 years ago, the concept of human resources was rarely known. In today's society, China's small and medium-sized enterprises are in the initial stage, and their strengths in all aspects are relatively poor. The concept of human resources is lagging behind, resulting in insufficient human resources departments and staffing, therefore, the imperfect human resource management system of many companies and the backwardness of human resources management mode. In addition, due to its informality and flexibility, SMEs must quickly adjust their personnel policies for various market opportunities and challenges, such as employee appointments, promotions, performance evaluations and employee vacations. And these jobs are done by a small number of HR managers while most of them are not well trained in professional human resources, so the management effect is rather poor. For example, if the employees with core competitiveness are not motivated, it will lead to loss of talents and insufficient training will directly affect the company's overall business level and lower business performance.

\section{B. Non-professional Recruitment Team}

Many small and medium-sized enterprises are difficult to recruit excellent employees. On one hand, small and medium-sized enterprises are not well-known and smallscale, and excellent talents are generally preferred to consider well-known enterprises or larger enterprises in the process of finding a job. So SMEs need to pay higher compensation to attract relatively good employees. On the other hand, the recruitment team members of SMEs are less professional and many are relatives of the boss. In the process of recruiting or selecting talents, they are rather subjective and willing to recruit their relatives and friends. They lacked the correct professional career description and career orientation for each position, and did not systematically examine the authenticity of the resume. In addition, the recruitment channels for SMEs are relatively narrow. Generally speaking, the recruitment of large enterprises is divided into internal recruitment and external recruitment. The enterprises are recruited through various channels, excellent talents can also be invited to visit the company, they can have a certain perception and understanding of the culture of corporate, and so enterprises can increase attractiveness to talented people from all aspects. So SMEs should set up professional recruitment teams and recruitment departments to make the recruitment to be regularized, in order to reduce the talent loss rate caused by personal subjectivity.

\section{The Incentive Mechanism Has No Regulatory Guarantees}

In the management of SMEs in China, the incentive mechanism for employees is generally formalistic and will be affected by the personal will of the managers. Business owners usually rely on their personal will to determine 
rewards and punishments for employees, and there are no regulatory guarantees. In terms of the construction of incentive mechanism for human resources management in China, many enterprises use market mechanisms to motivate and manage employees. They do not really address the needs of employees and protect the interests of their staffs. Many incentive policies are left behind and literally play no role in corporate management.

\section{Lack of Enterprise Salary Concept}

There is a lot of reasons for the lack of a scientific compensation system for SMEs. One aspect is that enterprises lack the awareness of establishing a comprehensive compensation concept. They do not really pay attention to the construction of the compensation system. The compensation of employees is often determined by the boss directly using his personal opinion and experience. Many private enterprises did not hire professional human resources personnel to design compensation schema. They did not seriously evaluate job descriptions and qualifications, nor did they carefully design compensation levels and adjusted the current compensation levels according to market environments. The chaos of internal compensation standards will hurt the long-term development of the company [3].

\section{E. Corporate Training Management Mistakes}

Currently, full-time training businesses in enterprises are usually operated by line managers or front-line managers. Because of the limitations of resources in SMEs, most of the trainers are not professional trainers, they are busy with their usual work, result in formalistic training. Some small and medium-sized enterprises will hire expensive professional trainers to train their employees. But the hired trainers do not understand what's going on inside the enterprise, so it is difficult to pinpoint the problems of the enterprises and the training content is far from the actual situation of the enterprise, which leads to ineffective training. Only when the managers of SMEs can stand on the employee's point of view and let the talents in the enterprise see the future development and promotion opportunities, can they enhance the attractiveness of their companies to talents.

\section{F. Deeply Influenced by Traditional Culture}

Confucianism originated in China, has a profound impact on Chinese traditional culture, and has played an important role in the formation of Chinese corporate culture. The Confucian culture emphasizes respect for authority, especially the respect for parents and teachers, and emphasizes the importance of hard work, discipline, harmony of interpersonal relations and the importance of the group. This value is reflected in the culture of small and medium enterprises, and highlights the important role of the enterprise leaders in the enterprise, and the employees of the enterprise are only subject to absolute obedience [4]. The doctrine of the mean in Confucianism emphasizes that people do not take extreme style in their lives. It shows that they pursue steady and not aggressive in their management style. In such an environment of absolute obedience, many people find it difficult to achieve the realization of self-worth.
However, a good working atmosphere and working environment are very important to employees. Everyone wants to realize self-worth under a good working environment and hopes to be respected by the company. Therefore, it is important to create an atmosphere of mutual respect and mutual concern among colleagues. Many companies are pursuing efficiency and want to create a competitive atmosphere among employees, but the result is often counterproductive. Creating a good working environment is also an effective way to avoid talent loss.

\section{RECOMMENDATIONS FOR HUMAN RESOURCES MANAGEMENT IN SMES}

\section{A. Establish a Complete Human Resources Management System}

First of all, we must establish a complete human resources management system in SMEs. The human resources management system includes new recruitment, job safety, employee relations, compensation and benefits, labor law compliance and training and development. We must standardize human resources management works, conscientiously formulate and conscientiously implement a strict management system and use the system to constrain and motivate employees and keep the company's human resource management system completely and orderly. At the same time, SME owners should also put some effect in improving their business level and management knowledge. We must resolutely reform the backward family-member based management system and select talents according to market requirements. The situation of cronyism within the enterprise must be strictly purged and treat every employee equally.

\section{B. Establish Long-term Human Resource Planning}

On one hand, SMEs should make a long-term recruitment plan based on the actual situation of their own company. Firstly, employers can make a prediction of future earnings, and then estimate the short- and long-term staff requirement that needs to be employed to accomplish the income target. Under the increasingly fierce market competition, business operation is constantly changing and developing and SMEs need to expand or reduce the business scale accordantly, which requires the management and planning of human resources. During the planning, we must also consider a lot of situations such as the status of human resources market, the expected resignation rate of enterprise personnel, product decision, productivity changes and changes of the company's business areas. On the other hand, SMEs have disadvantages in attracting talents compared to large enterprises. As a SME HR, one should make the applicants feel more sincere and professional. It is necessary to seize the candidate's concern and broaden the recruitment channels. We must take the initiative to find talents and use our sincerity to make the candidates choice our company. 


\section{Establish an Effective Incentive Mechanism to Fully Protect the Rights of Employees}

One of the most important reasons for the large amount of talent loss in the development of China's small and medium-sized enterprises is the lack of effective incentive mechanism. Many employees fail to feel the value of themselves during their work, which has hampered the enthusiasm of employees. Therefore, it is very important to establish an effective incentive mechanism to fully protect the rights of the employees. There are a variety of approaches of incentives. Companies can consider core employee shareholding systems, increase employee assignment opportunities, improve insurance and benefits, provide more vacations and improve the work environment. Establish an incentive mechanism welcomed by most employees, and closely link the incentives with the performance of employee's daily work to fully motivate employees.

\section{Establish a Comprehensive Compensation Management}

SMEs should establish a comprehensive compensation management system. The compensation management system of an enterprise consists of three parts: basic compensation, variable compensation and indirect compensation. Basic compensation refers to the stable income of employees in the work of small and medium-sized enterprises, thus the basic income. Variable compensation refers to some floating compensation or rewards. Indirect compensation mainly contains employee benefits, medical insurance and pension insurance. SMEs should improve the chaotic situation of compensation standards, comprehensively establish the concept of compensation within the company and actively manage employees' compensation according to market situation to improve employees' enthusiasm for their work.

\section{E. Establish a Good Working Environment and Corporate Culture of Learning}

At the end of the 1970s, Japan's economic strength had greatly increased and some products dominated the markets in European and American. The reason was that the Japanese not only focused on improving their professional abilities, but also paid great effects to establish cultural atmosphere, ensure cohesiveness of their employees and emphasized the role of their employees. Therefore, corporate culture has become an important part of a companies' core competitiveness. During the construction of corporate culture, we must combine the short-term interests of the company with the long-term interests of the company, consider both the personal development of employees and the long-term development of the company, create an atmosphere of mutual respect and mutual concern among colleagues to further retain talents and improve the efficiency of the company. Also, because of the neglect of training for SME owners, a culture of learning should be established to play a guiding role in promoting employee learning, enhancing employees' learning awareness, and mobilizing employees' enthusiasm for learning [5]. Establish a learning atmosphere to make SME owners and employees put their interests in business and profession. Therefore, establishing a good working environment and corporate culture of learning is very important for SMEs.

\section{CONCLUSION}

At present, the human resource management of small and medium enterprises in China is still in the primary stage of reform. There are many problems and the situation is not optimistic. The enterprise manager must set up the concept of human resource management and attach importance to human resource management according to the actual situation. The strategy of human resource management can continuously improve the management level of enterprises and achieve healthy and orderly development of enterprises.

\section{REFERENCES}

[1] Change and continuity in management systems and corporate performance: Human resource management, corporate culture, risk management and corporate strategy in South Korea $[\mathrm{J}]$. Woo Jun,Chris Rowley. Business History. 2014(3)

[2] Human resource performance predictors based on the human energy profile[J]. Andronicus Torp,Andreia Gabriela Andrei,Anca Alexandra Purcarea. Proceedings of the International Conference on Business Excellence. 2018(1).

[3] Human Resource Reforms in Public Administration: The Importance of the Reward System[J]. Christopher De Freitas Bradley. Holistica Journal of Business and Public Administration. 2017(2)

[4] Human Resources - Important Resources of the Contemporary Organization[J]. Elisabeta-Emilia Halmaghi,Lidia-Marinela Bacila International conference Knowledge-based Organization. 2018(1).

[5] The importance of human resources within the strategic direction and organizational success[J]. Maria Magdalena Criveanu,Silviu Cârstina. Proceedings of the International Conference on Business Excellence. 2018(1). 